\title{
Serotonin (5-HT) release in the hippocampus following various conditions and treatments affecting 5-HT receptors has been studied in vivo mainly by the means of brain micro-dialysis: A review
}

\author{
Francesco Crespi* \\ Biology, GSK, Verona, Italy
}

Serotonin or 5-hydroxytryptamine $(5-\mathrm{HT})$ is a monoamine neurotransmitter [1]. Biochemically derived from tryptophan, serotonin is primarily found in the gastrointestinal tract, platelets, and in the central nervous system (CNS) of animals including humans [2-4].

The hippocampus is a major component of the CNS, belongs to the limbic system and plays important roles in the consolidation of information from short-term memory to long-term memory as well as in spatial memory. Neurons in the hippocampus receive a strong serotonergic projection from the raphe nuclei and the majority of 5-HT receptor subtypes are expressed there: they can have either complementary or opposing effects on cell function, adding to the complexity of 5-HT neurotransmission. Indeed, the hippocampus plays an important role in emotional and cognitive processing, and both of these domains are affected in patients with major depressive disorder (MDD) [5]. Among the molecular, cellular, and systemic events that have been proposed to modulate the function of the hippocampus one of the most frequently cited possibilities is the activation of the serotonergic system [6]. Several preclinical research and clinical observations that modulation of serotonin (5HT) neurotransmission plays a key role in the therapeutic efficacy of selective serotonin reuptake inhibitors (SSRIs) on MDD support the assumption that 5-HT is important for hippocampal function in normal and disease-like conditions [5]. Neurons in the hippocampus receive a strong serotonergic projection from the raphe nuclei and the majority of 5-HT receptor subtypes are expressed there: they can have either complementary or opposing effects on cell function, adding to the complexity of 5-HT neurotransmission.

In particular, in vivo preclinical research has been performed mainly with the electrochemical methodology of micro-dialysis. Here a brief review on the 5-HT detection following different conditions and treatments affecting the 5-HT system and the various 5-HT receptors is proposed.

Already, in 1989, Sharp and Coll. [7] had proposed the feasibility of monitoring changes of 5-hydroxytryptamine (5-HT) release in the ventral hippocampus of the chloral hydrate-anaesthetized rat in response to systemic administration of a variety of $5-\mathrm{HT}_{1}$ receptor agonists. However, basal levels of 5-HT in the dialysates were close to detection limits when using HPLC with electrochemical detection. Addition of the selective 5-HT reuptake inhibitor (SSRI) citalopram $\left(10^{-6} \mathrm{Mol}\right)$ to the perfusion medium produced readily measurable amounts of dialysate 5-HT. Therefore it was used throughout the experiment and under such conditions. Injection of the 5- $\mathrm{HT}_{1 \mathrm{~A}}$ agonist 8 -hydroxy-2-(di- $n$-propylamino) tetralin (8-OHDPAT, 0.5 and $2.5 \mu \mathrm{g}$ ) into the dorsal raphe nucleus caused a dose-related fall in hippocampal output of 5-HT compared to saline-injected controls. Accordingly, the putative $5-\mathrm{HT}_{1 \mathrm{~A}}$ agonists gepirone (5 $\mathrm{mg} \mathrm{kg}^{-1}$, s.c.), ipsapirone $(5 \mathrm{mg}$ $\mathrm{kg}^{-1}$, s.c.) and buspirone (5 $\mathrm{mg} \mathrm{kg}^{-1}$, s.c.) significantly reduced levels of 5-HT in hippocampal perfusates, whereas their common metabolite 1-(2-pyrimidinyl) piperazine ( $5 \mathrm{mg} \mathrm{kg}^{-1}$, s.c.), which does not bind to central 5- $\mathrm{HT}_{1 \mathrm{~A}}$ recognition sites, had no effect.

Performing similar experiments, Hutson and Coll. (1989) [8] obtained similar data i.e. infusion of 8-OHDPAT $(0.5,1.0$ and $2.0 \mu \mathrm{g})$ into the dorsal raphe decreased extracellular 5-HT levels as measured by dialysis in the ventral hippocampus and also decreased 5-HT synthesis in both the hippocampus and the rest of the brain, as measured by 5-hydroxytryptophan (5-HTP) accumulation following decarboxylase inhibition by NSD 1015 .

Sharp and Coll. (1989b) [9] also showed that electrical stimulation (1-ms pulse width, $300 \mu \mathrm{A}, 2-20 \mathrm{~Hz}$ ) of the dorsal raphe nucleus for 20 minutes caused a rapid increase in hippocampal 5-HT output, which immediately declined on cessation of the stimulus and was frequencydependent. Addition of tetrodotoxin $\left(10^{-6} \mathrm{M}\right)$ to the perfusion medium reduced 5 -HT levels to $75 \%$ compared to pre-drug values. Their conclusion is that the spontaneous output of endogenous 5-HT to hippocampal dialysates predominantly originates from central 5-HT neurones and changes in accordance to their electrical activity.

In contrast to such conclusions includes data from Adell and Coll. (1993) [10]. These authors used in vivo micro-dialysis to monitor basal output of 5-HT in the dorsal and median raphe nuclei of the rat and showed the increase in this after $\mathrm{KCl}$ was added to the perfusion fluid. In contrast, neither the omission of calcium ions nor the addition of $0.5 \mathrm{nM}$ tetrodotoxin affected dialysate 5 -HT or 5-hy-droxyindoleacetic acid (5-H1AA). Reserpine did not decrease the output of 5-HT or 5-HIAA $24 \mathrm{~h}$ later and p-chloroamphetamine increased 5-HT in both vehicle and reserpine-treated rats. 8-OH-DPAT at 1 or $10 \mu \mathrm{M}$, when

Correspondence to: Francesco Crespi, Biology, GSK, Verona, Italy. Emailfm.crespi@libero.it

Received: October 10, 2017; Accepted: October 24, 2017; Published: October 27,2017 
Crespi F (2017) Serotonin (5-HT) release in the hippocampus following various conditions and treatments affecting 5-HT receptors has been studied in vivo mainly by the means of brain micro-dialysis: A review

perfused into the raphe did not change the outputs of 5-HT or 5-HIAA. Higher doses (up to $10 \mathrm{mM}$ ) increased extracellular 5-HT in the raphe, probably via an inhibition of uptake. In animals bearing two probes (raphe nuclei and ventral hippocampus), only the $10 \mathrm{mM}$ dose of $8-\mathrm{OH}$ DPAT perfused into the raphe decreased the hippocampal output of 5 -HT and 5-HIAA. The systemic injection of $0.1 \mathrm{mg} / \mathrm{kg} 8-\mathrm{OH}-\mathrm{DPAT}$ decreased dialysate 5-HT and 5-HIAA in the raphe and hippocampus. These results suggest that extracellular 5-HT in raphe nuclei originates from a cytoplasmic pool and is not dependent on either nerve impulse of 5-HT neurons or local activation of

5-HT ${ }_{1 \mathrm{~A}}$ receptors. similar data and conclusions have been obtained by means of differential pulse voltammetry with microbiosensors (DPV-mCFE) i.e. the second major in vivo electrochemical methodology for in vivo analysis of central serotoninergic activities [11]. Again, as well as DPV-mCFE [12] the micro-dialysis technique has also been functional to analyse the efficacy of the serotonin (5-HT) releaser $d$-fenfluramine and its active metabolite $d$-norfenfluramine, or the 5-HT-uptake inhibitor citalopram, to increase synaptic 5-HT availability [13]. Furthermore, it was observed that this facilitated an in vivo release of acetylcholine (ACh) from dorsal hippocampi of freely moving rats. This increase in extracellular ACh content induced by $d$-norfenfluramine $(5 \mathrm{mg} / \mathrm{kg}$ i.p.) was antagonized by the combination of $5-\mathbf{H T}_{3}$ receptor antagonists tropisetron $(0.5 \mathrm{mg} / \mathrm{kg}$ i.p.) and DAU 6215 (60 $\mu \mathrm{g} / \mathrm{kg}$ i.p.), but not by the mixed 5-HT and $5-\mathrm{HT}_{2}$ receptor antagonist metergoline $(2 \mathrm{mg} / \mathrm{kg}$ s.c.). Accordingly, the selective $5-\mathrm{HT}_{3}$ receptor agonist 2 -methyl-serotonin $(250 \mu \mathrm{g}$ i.c.v., or $10 \mu M$ applied by reverse dialysis) raised ACh release. The effect of the intracerebroventricular drug was prevented by the $5-\mathrm{HT}_{3}$ antagonists DAU $6215(60 \mu \mathrm{g} / \mathrm{kg}$ i.p.) and ondansetron $(60 \mu \mathrm{g} / \mathrm{kg}$ s.c.). These antagonists by themselves did not modify basal ACh release, indicating that 5 -HT does not tonically activate the $5-\mathrm{HT}_{3}$ receptors involved. The conclusion was that the overall regulatory control exerted by 5 -HT in vivo facilitates hippocampal ACh release. This is mediated by $5-\mathrm{HT}_{3}$ receptors, thought to be located in the dorsal hippocampi.

Observation that 5 - $\mathrm{HT}$ release in the ventral hippocampus is modulated by $5-\mathrm{HT}_{3}$ receptors has been supported by the evidence that infusion into the hippocampus for $15 \mathrm{~min}$ of the selective $5-\mathrm{HT}_{3}$ receptor agonist, 2-methyl-5-hydroxytryptamine (2-methyl-5-HT; 0.1-10 $\mu \mathrm{m}$ ) increased dialysate 5-HT levels in a concentration-related manner, an effect which was abolished by concurrent infusion of 3-tropanyl-3,5-dichlorobenzoate ( $1 \mu \mathrm{m}, \mathrm{MDL} 72222$ ), a selective 5-HT antagonist [14]. In contrast, RU 24969 a selective

$5-\mathrm{HT}_{1 \mathrm{~B}}$ receptor agonist, decreased 5-HT release in a dose- and concentration-related manner when administered i.p. (1 and $5 \mathrm{mg}$ $\left.\mathrm{kg}^{-1}\right)$ or via the dialysis probe $(0.1$ and $1 \mu \mathrm{m})$ respectively. The effect of RU 24969 infusion $(1 \mu \mathrm{m})$ was attenuated by concurrent infusion of metitepine $(10 \mu \mathrm{m})$ into the hippocampus. These data show that $5-\mathrm{HT}_{3}$ and 5- $\mathrm{HT}_{1 \mathrm{~B}}$ receptors have opposing roles in the control of $5-\mathrm{HT}$ release in the hippocampus, with $5-\mathrm{HT}_{3}$ receptors facilitating and $5-\mathrm{HT}_{1 \mathrm{~B}}$ receptors inhibiting 5 - $\mathrm{HT}$ efflux. It is also indicated that the facilitatory $5-\mathrm{HT}_{3}$ receptors are not tonically activated.

In vivo micro-dialysis experiments by Trillat and Coll. (1997) [15] did show in the frontal cortex and ventral hippocampus that basal and $\mathrm{K}^{+}$-evoked 5-HT release did not differ between conscious wild-type mice and homozygous mutant mice lacking the gene encoding the $5-\mathrm{HT}_{1 \mathrm{~B}}$ receptor. The infusion via reverse micro-dialysis of the selective $5-\mathrm{HT}_{1 \mathrm{~B}}$ receptor agonist CP-93,129 (500 $\left.\mathrm{nM}\right)$ decreased significantly $\mathrm{K}^{+}$-evoked 5-HT release in the frontal cortex (by $-44 \%$ ) and ventral hippocampus (by -32\%) of wild-type mice, but had no effect in mutants. In a similar manner, the mixed $5-\mathrm{HT}_{1 \mathrm{~B}}-\mathbf{5}-\mathbf{H T}$ receptor agonist sumatriptan $(800 \mathrm{nM})$ decreased $\mathrm{K}^{+}$-evoked 5-HT release significantly in the frontal cortex (by $-46 \%$ ) of wild-type mice, but had no effect in mutants. These results demonstrated that $5-\mathrm{HT}_{1 \mathrm{~B}}$ knockout mice are not as sensitive to full $(\mathrm{CP}-93,129)$ and mixed (sumatriptan) 5 - $\mathrm{HT}_{1 \mathrm{~B}}$ receptor agonists as wild-type mice. These data provide in vivo evidence that, in mice, $5-\mathrm{HT}_{1 \mathrm{~B}}$, but not $5-\mathrm{HT}_{1 \mathrm{D}}$, autoreceptors inhibit 5-HT release at nerve terminals located in the frontal cortex and ventral hippocampus.

In rats prepared for micro-dialysis and subjected to the Vogel type conflict test, significant increase of 5-HT release was monitored in the dorsal hippocampus, while pre-treatment with Midazolam (0.75 and $1.5 \mathrm{mg} / \mathrm{kg}$ i.p.) suppressed the dosage-dependently increased 5-HT release and attenuated conflict behaviour. These findings suggest that the activation of serotonergic neuronal activity in the dorsal hippocampus is linked to mediation of anxiety-related behaviour [16].

Possibly conflicting data about the modulation of 5-HT release by opioid receptors in the hippocampus evaluated by use of in vivo micro-dialysis were proposed: i) Tao and Hauerbach (1995) [17] showed increased extracellular serotonin in ventral hippocampus after systemic morphine (10 mg/kg, s.c.); ii) in contrast when hippocampus was perfused with morphine, $\left(0.1\right.$ to $10 \mu \mathrm{M}$, with $\left.\mathrm{K}^{+} 120 \mathrm{mM}\right)$ cresconcentration-dependent reduction of 5-HT release was produced, that was blocked in a dose-dependent manner by naltrexone ( 0.03 to 3 $\mathrm{mg} / \mathrm{kg}$, i.p.), a relatively selective $\mu$-opioid receptor antagonist.

By using a micro-dialysis approach, it has been shown that High-Frequency Stimulation [HFS] of the Subthalamic Nucleus and 1-3,4-Dihydroxyphenylalanine (1-DOPA) (i.e. the most used therapeutic approaches in Parkinson's disease) inhibited 5-HT levels in the prefrontal cortex (PFC) and hippocampus of sham-lesioned and 6-hydroxydopamine (6-OHDA)-lesioned anesthetized rats [18]. In particular, HFS did not further decrease 5-HT levels induced by l-DOPA 6 and $12 \mathrm{mg} / \mathrm{kg}$, but attenuated l-DOPA-induced dopamine release in the PFC and hippocampus. These data may suggest that the decrease in 5-HT levels induced by l-DOPA may be related to l-DOPAinduced dopamine release in the PFC and hippocampus, two brain regions involved in the regulation of mood and cognition, although it does not exclude its direct action inside serotonergic neurons.

A study by Matsumoto et al., (1995) [19] indicates the possibility that both exogenous and endogenous 5-HT inhibits NE release occurring from the rat hippocampus, and that functional modulation of NE release occurs via 5-HT3 receptors. Indeed they showed that $\mathrm{K}(+)$-evoked NE release was inhibited in a concentration-dependent manner when serotonin (5-HT, 0.01-10 $\mu \mathrm{M})$ was co-perfused with $\mathrm{K}+$. A selective 5-HT3 receptor agonist, 2-methyl-5-HT, mimicked the 5-HT response at a concentration of 0.01 to $10 \mu \mathrm{M}$. The 5-HT-induced $(1 \mu \mathrm{M})$ inhibition of NE release was blocked by pre-treatment with ondansetron ( 1 and $10 \mu \mathrm{M})$, a 5-HT3 receptor antagonist. $\mathrm{K}(+)$-evoked NE release was also reduced by co-perfusion with the 5-HT reuptake inhibitor, fluoxetine $(10 \mu \mathrm{M})$, which caused an increase in the dialysate 5 -HT concentration. The fluoxetine-induced inhibitory effect was furthermore abolished by pre-treatment with ondansetron ( 1 and 10 $\mu \mathrm{M})$.

Activation of Hippocampal 5-HT1A autoreceptors i.e. with the 5-HT1A agonist $(+) 8$-OH-DPAT as well as with antipsychotics such as SSR181507, SLV313, sarizotan results in decreased 5-HT and with enhanced treatment of negative symptoms and cognitive deficits. 
Crespi F (2017) Serotonin (5-HT) release in the hippocampus following various conditions and treatments affecting 5-HT receptors has been studied in vivo mainly by the means of brain micro-dialysis: A review

These 5-HT1A agonists increased dopamine levels in medial prefrontal cortex. These effects on Hippocampal 5-HT or on cortical dopamine were reversed by the selective 5-HT1A antagonist, WAY100635 supporting the mediation by 5 -HT1A receptors [20].

Further research has shown that when coupled with weak D2 antagonism 5-HT2A antagonism may also produce atypical antipsychotic drugs (APDs such as quetiapine, olanzapine, risperidone, i.e. drugs able to achieve an antipsychotic effect with lower rates of extrapyramidal side effects compared to first-generation APDs such as haloperidol).

APDs act preferentially on5-HT2A and 5-HT1A receptors located on glutamatergic pyramidal neurons in the cortex and hippocampus, 5-HT2A receptors on the cell bodies of DA neurons in the ventral tegmentum and substantia nigra and GABAergic interneurons in the cortex and hippocampus, and 5-HT1A receptors in the raphe nuclei. Evidence has accumulated also for the important modulatory role of 5-HT2C and 5-HT6 receptors for some of the effects of some of the current APDs [21].

In particular, the non-selective 5-HT2 receptor antagonist ketanserin produced a robust augmentation of citalopram-, fluoxetine-, and sertraline-induced elevations of extracellular serotonin levels in the hippocampal as well as cortical microdialysate in rats: two regions that have been strongly implicated in the pathophysiology of depressive disorders and in responses to antidepressant drugs. Similar potentiation of SSRI-induced increases in hippocampal serotonin levels was reproduced by the $5-\mathrm{HT} 2 \mathrm{C}$ receptor-selective antagonists SB 242084 and RS 102221. [22].

Antagonists at 5-HT3 receptors (tropisetron, ondansetron) produced antidepressant-like effects in rodents [23], they may mimic a direct receptor interaction of some clinically effective antidepressants, including fluoxetine, that have been reported to functionally block 5-HT3 receptors [24]. On the other hand, the 5-HT3 receptor agonist 1-( m-Chlorophenyl)-biguanide attenuated the effects of antidepressant compounds in the rat forced swimming test (FST) [25].

The 5-HT4 receptor is distributed widely in limbic regions of the brain and pharmacological blockade or genetic deletion of the 5 -HT4 receptor result in anxiolytic effects [26,27]. Combination of 5-HT4 receptor agonists such as RS 67333 with SSRIs [i.e. citalopram, fluoxetine] result in rapid onset of a number of adaptations usually requiring chronic treatment with SSRIs alone [28]. They also regulate acetylcholine release [29] so that they may act as memory facilitators.

The highest density of 5-HT6 receptors are located in the striatum, nucleus accumbens, olfactory tubercle, and cortex. They regulate the release of a number of neurotransmitters. This may play a role in their effectiveness in treating psychiatric disorders. Indeed, i] selective 5-HT6 receptor agonists and antagonists have both been reported to produce cognitive enhancing effects in rodents [30]; ii] agonists such as EMDT produce antidepressant and anxiolytic effects in a number of tests in mice and rats [i.e.reduced immobility] while antagonists such as SB271046 prevented the antidepressant effects of EMDT and fluoxetine [31]. Furthermore, both 5-HT6 receptor agonists and antagonists produce similar effects in animal tests for antidepressant activity [32] that may pass via facilitation of the release of norepinephrine or dopamine as they persisted after 5-HT depletion, suggesting that the effects were not dependent on endogenous serotonergic neurotransmission. In particular, the selective 5-HT6 receptor antagonist SB-399885 (1-3 $\mathrm{mg} / \mathrm{kg}$ i.p.) caused an anxiolytic-like activity comparable to that of diazepam $(2.5-5 \mathrm{mg} / \mathrm{kg}$ i.p.) in the Vogel conflict drinking test in rats i.e. behavioural test sensitive to clinically effective anxiolytic- and antidepressant-compounds. In FST, SB-399885 (10 mg/kg i.p. in rats; $20-30 \mathrm{mg} / \mathrm{kg}$ i.p. in mice) significantly shortened the immobility time and the effect was stronger than [in rats] or similar to [in mice] that of imipramine (30 mg/kg i.p.). Again, SB-399885 (3-20 mg/kg i.p. in rats; $30 \mathrm{mg} / \mathrm{kg}$ i.p. in mice) reduced the locomotor activity in the open field while did not affect motor coordination in mice and rats tested in the rota-rod test. [33].

In the medial thalamic nuclei, limbic, and cortical regions is the highest density of the

5-HT7 receptor suggesting their role in sensory and affective processes [34]. The selective expression of 5-HT7 receptors in the suprachiasmatic nucleus is consistent with a role in sleep or circadian rhythmic activity: indeed 5-HT7 receptor antagonists increased REM sleep in rats [35].

Reducing the function of 5-HT7 receptors i.e. via genetic deletion or administration of 5-HT7 receptor antagonists may produce AD-like behavioral effects in rodents [36,37]. More recently, antagonism to 5-HT7 receptors via atypical antipsychotic combined to antidepressants has been proposed as alternative therapy for refractory patients as well as to overlie the unwanted weeks delay in the onset of therapeutic action [38].

\section{References}

1. Bogdanski DF, Pletscher A, Brodie BB, Undenfriend S (1956) Identification and assay of serotonin in brain. J Pharmacol Exp Ther 117: 82-88. [Crossref]

2. Vialli M, Erspamer, V. (1933) Cellule enterocromaffini e cellule basigranulose acidofile nei vertebrati. Z. Zellforsch., 19: 743-745.

3. RAPPORT MM, GREEN AA, PAGE IH (1948) Serum vasoconstrictor, serotonin; isolation and characterization. J Biol Chem 176: 1243-1251. [Crossref]

4. Peroutka S, Howell TA (1994) The molecular evolution of G protein-coupled receptors: focus on 5-hydroxytryptamine receptors. Neuropharmacology 33: 319-324. [Crossref]

5. Schmitz D, Gloveli T, Empson R, Heinemann U. (1998) Comparison of the effects of serotonin in the hippocampus and the entorhinal cortex Mol Neurobiol 17: Issue 1-3, 59-72. [Crossref]

6. Dale E, Pehrson A, Jeyarajah T, Li Y et al. (2016) Effects of serotonin in the hippocampus: how SSRIs and multimodal antidepressants might regulate pyramidal cell function CNS Spectrum, Cambridge University Press 21: Issue 2, 143-161.

7. Sharp T, Bramwell SR, Grahame-Smith DG. (1989a) 5-HT1 agonists reduce 5-hydroxytryptamine release in rat hippocampus in vivo as determined by brain microdialysis Br J Pharmacol 96: 283-290. [Crossref]

8. Hutson P, Sarna G, O'Connell M, Curzon G (1989) Hippocampal 5-HT synthesis and release in vivo is decreased by infusion of 8-OHDPAT into the nucleus raphe dorsalis. Neurosci Lett. 100: 276-280. [Crossref]

9. Sharp T, Bramwell SR, Clark D, Grahame-Smith DG. (1989b) In Vivo Measurement of Extracellular 5-Hydroxytryptamine in Hippocampus of the Anaesthetized Rat Using Micro-dialysis: Changes in Relation to 5-Hydroxytryptaminergic Neuronal Activity. $J$ Neurochem 53: 234-240. [Crossref]

10. Adell A, Carceller A, Antigas F (1993) In Vivo Brain Dialysis Study of the Somatodendritic Release of Serotonin in the Raphe Nuclei of the Rat: Effects of 8-Hydroxy-2-(Di-n-Propylamino) tetralin J Neurochem 60: 1673-1681. [Crossref]

11. Crespi F, Garratt J, Sleight A, Marsden CA. (1990) Simultaneous in vivo monitoring of serotonin and 5-HIAA, evidence that 5-HT firing and 5-HT release are not necessarily reflected by changes in 5-HT metabolism.Neuroscience 35: 139-144. [Crossref]

12. Crespi F, Martin KF, Marsden CA. (1988) Nafion coated carbon fibre electrodes combined with differential pulse voltammetry measure $5 \mathrm{HT}$ release in vivo. Neuroscience 27: 885-896.

13. Consolo S, Bertorelli R, Russi G, Zimbelli M, LadinskyH. (1994) Serotonergic Facilitation of Acetylcholine Release In Vivo from Rat Dorsal Hippocampus via Serotonin 5-HT3 Receptors. J Neurochem 62: 2254-2261. [Crossref] 
Crespi F (2017) Serotonin (5-HT) release in the hippocampus following various conditions and treatments affecting 5-HT receptors has been studied in vivo mainly by the means of brain micro-dialysis: A review

14. Martin K, Hannon S, I, Phillips I, Heal D. (1992) Opposing roles for 5-HT1B and 5-HT3 receptors in the control of 5-HT release in rat hippocampus in vivo. $\mathrm{BrJ}$ Pharmacol 106: 139-142. [Crossref]

15. Trillat A, Malagié I, Scearce K, Pons D, Anmella MC et al. (1997) Regulation of Serotonin Release in the Frontal Cortex and Ventral Hippocampus of Homozygous Mice Lacking 5-HT1B Receptors: In Vivo Micro-dialysis Studies. J Neurochem 69: 2019-2025. [Crossref]

16. Matsuo M, Kataoka Y, Mataki S, Kato Y, Oi K. (1996) Conflict situation increases serotonin release in rat dorsal hippocampus: in vivo study with micro-dialysis and Vogel test. Neurosci Lett 215: 197-200. [Crossref]

17. Tao T, Auerbach S. (1995) Involvement of the dorsal raphe but not median raphe nucleus in morphine-induced increases in serotonin release in the rat forebrain Neuroscience 68: 553-561.

18. Navailles S, Benazzouz A, Bioulac B, Gross C, De Deurwaerdère P. (2010) HighFrequency Stimulation of the Subthalamic Nucleus and 1-3,4-Dihydroxyphenylalanine Inhibit In Vivo Serotonin Release in the Prefrontal Cortex and Hippocampus in a Rat Model of Parkinson's Disease. J Neurosci 30: 2356-2364. [Crossref]

19. Matsumoto M, Yoshioka M, Togashi H, Tochihara M, Ikeda T et al. (1995) Modulation of norepinephrine release by serotonergic receptors in the rat hippocampus as measured by in vivo micro-dialysis. J Pharmacol Exp Ther. 272: 1044-1051. [Crossref]

20. Assié M, Ravailhe V, Faucillon V, Newman-Tancredi A. (2005) Contrasting Contribution of 5-Hydroxytryptamine 1A Receptor Activation to Neurochemical Profile of Novel Antipsychotics: Frontocortical Dopamine and Hippocampal Serotonin Release in Rat Brain. J Pharmacol Exp Ther., 315: 265-272. [Crossref]

21. Meltzer H, Li Z, Kaneda Y, Ichikawa J. (2003) Serotonin receptors : their key role in drugs to treat schizophrenia. Prog Neuropsychopharmacol Biol Psychiatry, 27: 1159-1172. [Crossref]

22. Cremers T, Giorgetti M, Bosker F, Hogg S et al. (2004) Inactivation of 5-HT2C Receptors Potentiates Consequences of Serotonin Reuptake Blockade Neuropsychopharmacology, 29: 1782-1789. [Crossref]

23. Mahesh R, Rajkumar R, Minasri B, Venkatesha Perumal R. (2007) Potential antidepressants: pharmacology of 2-(4-methyl piperazin-1-yl)-1, 8-naphthyridine-3carbonitrile in rodent behavioural models. Pharmazie. 62: 919-924. [Crossref]

24. Eisensamer B, Rammes G, Gimpl G, Shapa M, Ferrari U, et al. (2003) Antidepressants are functional antagonists at the serotonin type 3 (5-HT3) receptor. Mol Psychiatry 8 : 994-1007. [Crossref]

25. Nakagawa Y, Ishima T, Takashima T (1998) The 5-HT3 receptor agonist attenuates the action of antidepressants in the forced swim test in rats. Brain Res 786: 189-193. [Crossref]
26. Conductier G, Dusticier N, Lucas G, Côté F, Debonnel G, et al. (2006) Adaptive changes in serotonin neurons of the raphe nuclei in 5-HT(4) receptor knock-out mouse. Eur J Neurosci 24: 1053-1062. [Crossref]

27. Smriga M, Torii K. (2003) L-Lysine acts like a partial serotonin receptor 4 antagonist and inhibits serotonin mediated intestinal pathologies and anxiety in rats. Proc Natl Acad Sci U S A. 100: 15370-15375. [Crossref]

28. Lucas G, Du J, Romeas T, Mnie-Filali O, Haddjeri N, et al. (2010) Selective serotonin reuptake inhibitors potentiate the rapid antidepressant-like effects of serotonin4 receptor agonists in the rat. PLoS One 5: e9253. [Crossref]

29. Meneses A (2007) Stimulation of 5-HT1A, 5-HT1B, 5-HT2A/2C, 5-HT3 and 5-HT4 receptors or 5-HT uptake inhibition: short- and long-term memory. Behav Brain Res 184: 81-90. [Crossref]

30. Fone KC1 (2008) An update on the role of the 5-hydroxytryptamine6 receptor in cognitive function. Neuropharmacology 55: 1015-1022. [Crossref]

31. Svenningsson P, Tzavara ET, Qi H, Carruthers R, Witkin JM, et al. (2007) Biochemical and behavioral evidence for antidepressant-like effects of 5-HT6 receptor stimulation. $J$ Neurosci 27: 4201-4209. [Crossref]

32. Weso $\AA$,owska A (2010) Potential role of the 5-HT6 receptor in depression and anxiety: an overview of preclinical data. Pharmacol Rep 62: 564-577. [Crossref]

33. Wesolowska A, Nikiforuk A. (2007) Effects of the brain-penetrant and selective 5-HT6 receptor antagonist SB-399885 in animal models of anxiety and depression Neuropharmacology 52: 1274-1283. [Crossref]

34. Hannon J, Hoyer D (2008) Molecular biology of 5-HT receptors. Behav Brain Res 195 198-213. [Crossref]

35. Bonaventure P, Kelly L, Aluisio L, Shelton J, Lord B et al. (2007) Selective blockade of 5-hydroxytryptamine (5-HT)7 receptors enhances 5-HT transmission, antidepressantlike behavior, and rapid eye movement sleep suppression induced by citalopram in rodents. J Pharmacol Exp Ther. 321: 690-698. [Crossref]

36. Guscott M, Bristow LJ, Hadingham K, Rosahl TW, Beer MS, et al. (2005) Genetic knockout and pharmacological blockade studies of the 5-HT7 receptor suggest therapeutic potential in depression. Neuropharmacology 48: 492-502. [Crossref]

37. Hedlund P, Huitron-Resendiz S, Henriksen SJ, Sutcliffe JG. (2005) 5-HT7 receptor inhibition and inactivation induce antidepressant-like behavior and sleep pattern. Biol. Psychiatry 58: 831-837. [Crossref]

38. Mnie-Filali O, Lambás-Señas L, Zimmer L, Haddjeri N (2007) 5-HT7 receptor antagonists as a new class of antidepressants. Drug News Perspect 20: 613-618. [Crossref]

Copyright: (C2017 Crespi F. This is an open-access article distributed under the terms of the Creative Commons Attribution License, which permits unrestricted use, distribution, and reproduction in any medium, provided the original author and source are credited. 